\title{
Review of Chemical Properties and Ethnomedicinal uses of Acanthosicyos horridus Welw. ex Hook. f.: An Indigenous Melon Species of South-West Coast of Africa
}

\begin{abstract}
Alfred Maroyi
Department of Botany, University of Fort Hare, Private Bag X1314, Alice 5700, South Africa

Abstract: Acanthosicyos horridus Welw. ex Hook. f. is a perennial shrub collected from the wild for its edible fruits and is also used as a traditional medicine. This study is aimed at evaluating the chemical properties and ethnomedicinal uses of $A$. horridus. Results of the current study are based on data derived from several online databases such as Scopus, Google Scholar, PubMed and Science Direct, and pre-electronic sources such as scientific publications, books, dissertations, book chapters and journal articles. This study revealed that the fruit and root infusions and/or decoctions of A. horridus are used as traditional medicine for arteriosclerosis, chest pains, gastro-intestinal disorders, kidney problems, nausea and sexually transmitted infections. Phytochemical compounds identified from the species include cucurbitacins, fatty acids and sterols. Some of the compounds identified from the species have applications in food industry and health promoting products.
\end{abstract}

Keywords: Acanthosicyos horridus, Cucurbitaceae, indigenous pharmacopeia, traditional medicine.

\section{INTRODUCTION}

Acanthosicyos horridus Welw. ex Hook. f. is a perennial shrub belonging to the Cucurbitaceae family, often called cucurbits or the gourd family. The Cucurbitaceae family consist of 95 genera and 965 species [1] with species of Cucumis L., Cucurbita L., Citrullus Schrad., Lagenaria Ser., Luffa Mill. and Momordica L. widely grown around the tropics and temperate areas for their edible fruits [2,3]. The majority of edible species of Cucurbitaceae family have economic importance as leafy vegetables, cucumbers, honeydew melons, melons, muskmelons and watermelons [4,5]. The genus Acanthosicyos Welw. ex Hook. f. consists of a single species, A. horridus which is endemic to the Namib Desert of the south-west coast of Africa and occurs from southern Angola, through Namibia to South Africa [6,7]. Acanthosicyos naudinianus (Sond.) C. Jeffrey (a synonym of Citrullus naudinianus (Sond.) Hook. f.) was transferred to the genus Acanthosicyos by Jeffrey [8] based on biochemical and seed coat characters, a view not accepted by Fursa $[9,10]$, and also contradicted by molecular data $[7,8,11,12]$. Such taxonomical problems have negative effect on ethnopharmacological research and conservation programmes targeting specific species and closely related species [13-17].

The genus name "Acanthosicyos" is a contraction of two terms, a Greek term "acantha" meaning "spine" or

*Address correspondence to this author at the Department of Botany, University of Fort Hare, Private Bag X1314, Alice 5700, South Africa;

Tel/Fax: 0027719600326; E-mail: amaroyi@ufh.ac.za "thorn" and a Latin term "sicyoideus" meaning "gourdshaped", that is, swollen below with narrow neck above, in reference to the spines on the fruit [18]. The specific name "horridus" is from a Latin verb "horrere" in reference to sharp thorns and the plant's ability to grow into impenetrable spiky thickets [19]. The English common names of $A$. horridus include nara, nara bush and nara melon. The seeds of $A$. horridus are known as butternuts or butterpips [20]. Acanthosicyos horridus is a perennial, dioecious and strongly branched shrub growing up to one metre tall and 40.0 metres in diameter [20]. The longitudinally grooved, pale yellow to green stems with spines arising from a very long and woody taproot system. The leaves are reduced to minute scales. The flowers are unisexual and yellow in colour. The fruit is a subglobose berry covered with spines, ripening from green to pale yellow or pale orange-yellow with many seeds. The seeds are oblong to ovoid in shape, hard with a thick testa and cream in colour, embedded in yellow to orange-yellow pulp. Acanthosicyos horridus has been recorded in the sand dunes of mostly dry riverbeds where subsurface water is available at an altitude ranging from $25 \mathrm{~m}$ to $150 \mathrm{~m}$ above sea level [21-24].

Acanthosicyos horridus is protected in Namibia [25] and in South Africa, and the species is poorly known with the last collection of the species in the country made in 1925 [26]. Acanthosicyos horridus is regarded as an important medicinal plant species in South Africa that is threatened or is of conservation concern and currently categorized as Least Concern (Data Deficient due to insufficient information) [27] using the IUCN Red

() 2020 SET Publisher 
List Categories and Criteria version 3.1 of threatened species. Previous reports show that $A$. horridus occurs in small, severely fragmented subpopulations and is potentially threatened by habitat loss due to mining, agricultural expansion and urbanization [26], and such species are of conservation concern $[28,29]$. The fruits of $A$. horridus are regarded as an important food source in Namibia [30-32]. Mansfeld et al. [33] argued that $A$. horridus is an incipiently cultivated plant with great promise for cultivation in arid areas as a source of food, fodder and herbal medicines. Research by Van Wyk $[34,35]$ and Van Wyk and Wink [36] revealed that the roots of $A$. horridus have commercial potential as traditional medicines while seed oil have commercial potential in the production of food products and cosmetics. Therefore, the aim of this review is to provide an integrated and detailed appraisal of the existing knowledge on the chemical properties, biological activities and ethnobotanical uses of $A$. horridus in an attempt to explore the therapeutic and functional potential of this species.

\section{Traditional uses}

Acanthosicyos horridus is an important food and medicinal plant species in the desert areas of Namibia and South Africa [37-46]. Before the introduction of maize (Zea mays L.) into southern Africa, $A$. horridus was a traditional staple food [47]. Archeological evidence indicates that it has been a staple food for desert dwellers in southern Africa for over 8000 years $[48,49]$. The seeds of $A$. horridus are eaten fresh or roasted as a snack food or ground into flour for cooking with other dishes or made into a traditional reserve or dried fruit pulp made into flat cakes. The seeds of $A$. horridus are a good substitute for almonds (Prunus dulcis (Mill.) D.A. Webb and are collected from the wild for use in the confectionery industry in South Africa [5053]. Young stems of $A$. horridus are browsed by livestock and game $[54,55]$ while the peels of fruits are fed to donkeys and goats and the pips to chicken [5658]. Therefore, the fruit deserves consideration for a selection and breeding programme [59].

In Namibia, the fruit and root infusions and/or decoctions of $A$. horridus are used as a traditional medicine for arteriosclerosis, chest pains, gastrointestinal disorders such as diarrhoea, stomach ache and stomach problems, kidney problems, nausea, sexually transmitted infections and venereal diseases (Table 1). The roots of $A$. horridus are mixed with fat and applied topically against wounds $[57,60,61]$ while seed oil of the species is applied topically as a skin moisturizer and against sunburn [20,57,60-62].

\section{Nutritional and Phytochemical Composition}

Several researchers such as Wilkins-Ellert [20], Joubert and Cooper [64], Tanaka [65], Wehmeyer [66], Eaton and Nelson [67], Klopatek and Stock [68], Velempini and Perkins [69], Yang and Keding [70] and Cheikhyoussef et al. [71] investigated the nutritional properties of $A$. horridus flowers, fruits, roots, seeds, seed oil and stems (Table 2). A wide variety of nutrients associated with different plant parts of $A$. horridus (Table 2) imply that the species could be a source of health promoting nutrients such as calcium, carbohydrates, copper, crude fibre, fat, iron, magnesium, phosphorus, potassium, proteins, sodium, vitamin $C$ and zinc [72-74]. These nutrients that were identified from different plant parts of $A$. horridus have applications in food industry and nutritive medicines. Based on these research findings, the fruits of $A$. horridus could serve as a good supplement for nutrients such as carbohydrates, crude fibre, fat

Table 1: Medicinal uses of Acanthosicyos horridus in Namibia

\begin{tabular}{|c|c|c|}
\hline Medicinal use & Plant part & Reference \\
\hline \hline Arteriosclerosis & Root infusion and/or decoction taken orally & {$[57,60,61,62]$} \\
\hline Chest pains & Root infusion and/or decoction taken orally & {$[57,60,61,62]$} \\
\hline $\begin{array}{c}\text { Gastro-intestinal disorders (diarrhoea, stomach ache and } \\
\text { stomach problems) }\end{array}$ & Fruit and root infusion and/or decoction taken orally & {$[20,57,60-63]$} \\
\hline Kidney problems & Root infusion and/or decoction taken orally & {$[57,60-62]$} \\
\hline Nausea & Root infusion and/or decoction taken orally & {$[20,57,60-62]$} \\
\hline Sexually transmitted infections and venereal diseases & Fruit infusion and/or decoction taken & {$[20,57,60-62]$} \\
\hline Skin moisturizer & Seed oil applied topically & {$[20,57,60-62]$} \\
\hline Sunburn & Seed oil applied topically & {$[20,57,60-62]$} \\
\hline Wounds & Roots mixed with fat and applied topically & {$[57,60,61]$} \\
\hline
\end{tabular}


Table 2: Nutritional and Phytochemical Composition of Acanthosicyos horridus

\begin{tabular}{|c|c|c|c|}
\hline Nutritional or phytochemical component & Value & Plant part & Reference \\
\hline \multicolumn{4}{|l|}{ Nutritional component } \\
\hline$\beta$-Tocopherol (\%) & $0.5-0.8$ & Seed oil & [71] \\
\hline Y-Tocopherol (\%) & $35.5-45.1$ & Seed oil & [71] \\
\hline Total tocopherol (\%) & $44.5-46.1$ & Seed oil & [71] \\
\hline$\beta$-carotene (mg/100g) & 0.1 & Fruits and stems & {$[20,66,70]$} \\
\hline Ash (mg/100g) & $1.6-3.4$ & Fruits and seeds & {$[66]$} \\
\hline Calcium (mg/100g) & $21.4-100.0$ & Fruits and seeds & {$[20,65-67]$} \\
\hline Dry matter (\%) & $16.0-94.7$ & Fruits and stems & [70] \\
\hline Energy (kJ) & $231.0-2709.0$ & Fruits and seeds & {$[20,65-67]$} \\
\hline Fat $(\mathrm{g} / 100 \mathrm{~g})$ & $0.3-57.0$ & Fruits and seeds & {$[20,66]$} \\
\hline Iron (mg/100g) & $0.5-4.0$ & Fruits and seeds & {$[20,66]$} \\
\hline Magnesium (mg/100g) & $19.0-363.0$ & Fruits and seeds & {$[20,66]$} \\
\hline Nicotinic acid (mg/100g) & 2.2 & Seeds & {$[20,66]$} \\
\hline Nicotinic acid (mg/100g) & $0.8-2.2$ & Fruits and seeds & {$[20,66]$} \\
\hline Nitrogen (mg/g) & $12.1-55.6$ & $\begin{array}{l}\text { Flowers, fruits, roots, seeds and } \\
\text { stems }\end{array}$ & [68] \\
\hline Thiamin (mg/100g) & 0.01 & Fruits & {$[20,66]$} \\
\hline Vitamin C (mg) & - & Fruits and stems & [70] \\
\hline Water (mg/100g) & $5.3-84.0$ & Fruits and seeds & {$[20,66,69]$} \\
\hline Zinc (mg/100g) & $0.6-5.5$ & Fruits and seeds & {$[20,66,70]$} \\
\hline \multicolumn{4}{|l|}{ Phytochemical component } \\
\hline Stigmasterol (\%) & $20.5-24.6$ & Seed oil & [71] \\
\hline$\beta$-Sitosterol (\%) & $19.8-26.8$ & Seed oil & [71] \\
\hline Palmitic acid (\%) & 15.6 & Seed oil & [71] \\
\hline Stearic acid (\%) & $11.6-11.9$ & Seed oil & [71] \\
\hline Oleic acid (\%) & $12.8-13.9$ & Seed oil & [71] \\
\hline Linoleic acid (\%) & $53.1-54.5$ & Seed oil & [71] \\
\hline Eicosenoic acid (\%) & 4.4 & Seed oil & [71] \\
\hline a-Eleostearic acid (\%) & 1.0 & Seed oil & [71] \\
\hline Total unsaturated fatty acids (\%) & $72.5-72.7$ & Seed oil & [71] \\
\hline Total saturated fatty acids (\%) & $27.3-27.5$ & Seed oil & [71] \\
\hline Cucurbitacin B & - & Fruits and roots & [75-77] \\
\hline
\end{tabular}




\begin{tabular}{|c|c|c|c|}
\hline Nutritional or phytochemical component & Value & Plant part & Reference \\
\hline Cucurbitacin D & - & Fruits and roots & {$[75-77]$} \\
\hline Cucurbitacin G & - & Fruits and roots & {$[75,77]$} \\
\hline Cucurbitacin $\mathrm{H}$ & - & Fruits and roots & {$[75,77,78]$} \\
\hline Dihydrocucurbitacin B & - & Roots & [76] \\
\hline 3-epi-iso-cucurbitacin D & - & Roots & [76] \\
\hline tetrahydro-iso-cucurbitacin I & - & Roots & {$[76]$} \\
\hline dihydro-epi-iso-cucurbitacin D & - & Roots & {$[76]$} \\
\hline Diacetyldihydro-epi-iso-cucurbitacin D & - & Roots & [76] \\
\hline
\end{tabular}

proteins and vitamin $\mathrm{C}$ to complement the stipulated requirements for the recommended dietary allowance (RDA) values [72] as the species is a traditional staple food of communities in the Namib Desert of the southwest of Africa [20].

Phytochemical compounds identified from the fruits, roots and seed oil of $A$. horridus include cucurbitacins, fatty acids and sterols [71,75-78]. The triterpenoids such as cucurbitacin $B, D, G$ and $H$, dihydrocucurbitacin $B$ and $D, 3$-epi-iso-cucurbitacin $D$, tetrahydroiso-cucurbitacin I, dihydro-epi-iso-cucurbitacin D, diacetyldihydro-epi-iso-cucurbitacin $\mathrm{D}$, tetrahydro-isoelatericin $B$ and raffinoseoligosaccharides have been identified from the fruits, roots and seed oil of $A$. horridus [75-79]. The bitter taste associated with the fruits of $A$. horridus is attributed to cucurbitacins, the bitter-tasting triterpenoids that are highly cytotoxic as some of them block mitosis in metaphase by inhibiting microtubule formation [80] and have purgative properties [81]. Some of these phytochemical compounds may be responsible for the biological activities of the species.

\section{FUTURE RESEARCH AND PERSPECTIVES}

Research on $A$. horridus over the past decades showed that the species is an important food plant in the dry areas of the south-west coast of Angola, Namibia and South Africa. The species is currently collected from the wild but previous research showed that $A$. horridus has great promise for cultivation in arid areas as a source of food, fodder and herbal medicines. ${ }^{20}$ Therefore, future research should focus on developing selection and breeding programmes aimed at developing a variety that can produce larger and more palatable fruits. Future research should also focus on identifying the phytochemical compounds and pharmacological properties of both these compounds and crude extracts of the species. Such comprehensive chemical characterization of both crude and pure extracts, and evaluation of commercial potential and development of nutraceutical products based on traditional uses of $A$. horridus is important. Recent increase in research focusing on $A$. horridus revealed conservation concerns about the species, particularly in South Africa. Cultivation of $A$. horridus is, therefore, a solution to the sustainability problems associated with harvesting of the species from the wild, and this option is also necessary for establishing commercial scale medicinal production and processing and trade enterprises.

\section{CONFLICT OF INTEREST}

No conflict of interest is associated with this work.

\section{REFERENCES}

[1] Christenhusz MJM, Byng JW. The number of known plants species in the world and its annual increase. Phytotaxa 2016; 261(3): 201-17. https://doi.org/10.11646/phytotaxa.261.3.1

[2] Jeffrey C. Cucurbitaceae. In Mansfeld R, Büttner R, Hanelt P (Eds.), Mansfeld's encyclopedia of agricultural and horticultural crops. Berlin: Springer, 2001, pp. 1510-57.

[3] Amar Z, Lev E. Watermelon, chate melon, and cucumber: New light on traditional and innovative field crops of the Middle Ages. J Asiatique 2011; 299: 193-204.

[4] Bates DM, Robinson RW. Cucumbers, melons and watermelons. In Smart J, Simmonds NW (Eds.), Evolution of crop plants. London: Longman, 1995, pp. 89-96.

[5] Gusmini G, Wehner TC. Fifty-five years of yield improvement for cucumber, melon, and watermelon in the United States. HortTechnol 2008; 18: 9-12. https://doi.org/10.21273/HORTTECH.18.1.9 
[6] Schaefer H, Renner S. Cucurbitaceae. In Kubitzki K (Ed.), Flowering plants: Eudicots. The families and genera of vascular plants vol 10. Berlin: Springer, 2010, pp. 112-74. https://doi.org/10.1007/978-3-642-14397-7 10

[7] Schaefer H, Heibl C, Renner SS. Gourds afloat: A dated phylogeny reveals an Asian origin of the gourd family (Cucurbitaceae) and numerous oversea dispersal events. Proceed Royal Soc B 2009; 276: 843-51. https://doi.org/10.1098/rspb.2008.1447

[8] Jeffrey C. Notes on Cucurbitaceae, including a proposed new classification of the family. Kew Bull 1962; 15: 333-71. https://doi.org/10.2307/4115586

[9] Fursa TB. On the taxonomy of genus Citrullus Schrad. Bot Zhurnal 1972; 57: 31-41.

[10] Fursa TB. On the evolution of the genus Citrullus Schrad. Bot Zhurnal 1972; 57: 1365-72.

[11] Chomicki G, Renner SS. Watermelon origin solved with molecular phylogenetics including Linnaean material: Another example of museomics. New Phytologist 2015; 205: 526-32.

https://doi.org/10.1111/nph.13163

[12] Renner SS, Sousa A, Chomicki G. Chromosome numbers, Sudanese wild forms, and classification of the watermelon genus Citrullus, with 50 names allocated to seven biological species. Taxon 2017; 66(6): 1393-405.

https://doi.org/10.12705/666.7

[13] Rivera $D$, et al. What is in a name? The need for accurate scientific nomenclature for plants. J Ethnopharmacol 2014; 152: 393-402.

https://doi.org/10.1016/j.jep.2013.12.022

[14] Dauncey EA, et al. Common mistakes when using plant names and how to avoid them. European $\mathrm{J}$ Integrative Med 2016; 8: 597-601. https://doi.org/10.1016/j.eujim.2016.09.005

[15] Ghorbani A, Saeedi Y, De Boer HJ. Unidentifiable by morphology: DNA barcoding of plant material in local markets in Iran. PLoS One 2017; 12(4): e0175722.

https://doi.org/10.1371/journal.pone.0175722

[16] Guzzon F, Ardenghi NMG. Could taxonomic misnaming threaten the ex situ conservation and the usage of plant genetic resources? Biod Cons 2018; 27: 1157-72. https://doi.org/10.1007/s10531-017-1485-7

[17] Sharma V, Restrepo MI, Sarkar IN. Solr-plant: Efficient extraction of plant names from text. BMC Bioinform 2019; 20: 263. https://doi.org/10.1186/s12859-019-2874-6

[18] Heath A, Heath R. Field guide to the plants of northern Botswana including the Okavango Delta. Richmond: Royal Botanic Gardens, Kew, 2009.

[19] Berry C. Nara: Unique melon of the desert. Veld FI 1991; 77(1): 22-3.

[20] Wilkins-Ellert MH. Acanthosicyos horridus Welw. ex Hook. f. In Grubben GJH, Denton OA (Eds.), Plant resources of tropical Africa 2: Vegetables. Wageningen: Backhuys Publishers; 2004, pp. 31-4.

[21] Meeuse ADJ. The Cucurbitaceae of southern Africa. Bothalia 1962; 8(1): 1-111.

https://doi.org/10.4102/abc.v8i1.1611

[22] Germishuizen G, Meyer NL. Plants of southern Africa: An annotated checklist. Pretoria: Strelitzia 14, National Botanical Institute; 2003.

[23] Figueiredo E, Smith GF. Plants of Angola. Pretoria: Strelitzia 22, South African National Biodiversity Institute; 2008.

[24] Snijman DA. Plants of the Greater Cape Floristic region, Vol. 2: The Extra Cape Flora. Pretoria: Strelitzia 30. South African National Biodiversity Institute; 2013.

[25] Mannheimer CA, Curtis BA. Le Roux and Muller's field guide to the tree and shrubs of Namibia. Windhoek: Macmillan Education; 2009.
[26] Raimondo D, et al. Red List of South African plants. Pretoria: Strelitzia 25, South African National Biodiversity Institute; 2009.

[27] Williams VL, Victor JE, Crouch NR. Red Listed medicinal plants of South Africa: Status, trends, and assessment challenges. S Afr J Bot 2013; 86: 23-35. https://doi.org/10.1016/j.sajb.2013.01.006

[28] Victor JE, Keith M. The Orange list: A safety net for biodiversity in South Africa. S Afr J Sci 2004; 100: 139-41.

[29] Von Staden L, Raimondo D, Foden W. Approach to Red List assessments. In Raimondo D, et al. (Editors), Red List of South African plants. Pretoria: Strelitzia 25, South African National Biodiversity Institute; 2009, pp. 6-16.

[30] Arnold TH, Wells MJ, Wehmeyer AS. Khoisan food plants: Taxa with potential for future economic exploitation. In Wickens GE, Goodin JR, Field DV (Eds.), Plants for arid lands. London: Proceedings of the Kew International Conference on Economic Plants for Arid Lands, Allen and Unwin; 1985, pp. 69-86.

https://doi.org/10.1007/978-94-011-6830-4 6

[31] Bosch CH. Acanthosicyos naudinianus (Sond.) C. Jeffrey. In Grubben GJH, Denton OA (Eds.), Plant resources of tropical Africa 2: Vegetables. Wageningen: Backhuys Publishers; 2004; pp. 34-5.

[32] Gray L. Flowering plants: A pictorial guide to the world's flora. New York: Firefly Books; 2011.

[33] Mansfeld R, Büttner R, Hanelt P. Mansfeld's encyclopedia of agricultural and horticultural crops (except ornamentals) vol 2. Berlin: Springer; 2001.

[34] Van Wyk B-E. A review of commercially important African medicinal plants. J Ethnopharmacol 2015; 176: 118-34. https://doi.org/10.1016/j.jep.2015.10.031

[35] Van Wyk B-E. A review of African medicinal and aromatic plants. In Neffati M, Najjaa H, Mathé A (Eds.), Medicinal and aromatic plants of the world: Africa vol 3. Berlin: Springer; 2017, pp. 19-60. https://doi.org/10.1007/978-94-024-1120-1 2

[36] Van Wyk B-E, Wink M. Medicinal plants of the world. Pretoria: Briza Publications; 2017. https://doi.org/10.1079/9781786393258.0000

[37] Levinson $O$. The ageless land. Cape Town: Tafelberg Uitgewers; 1961.

[38] Smith CA. Common names of South African plants. Pretoria: Botanical Survey Memoir No. 35, Department of Agricultural Technical Services; 1966.

[39] Fox FW, Norwood Young ME. Food from the veld. Johannesburg: Delta Books; 1982.

[40] Arnold $\mathrm{TH}$, et al. Medicinal and magical plants of Southern Africa: An annotated checklist. Pretoria: Strelitzia 13, National Botanical Institute; 2002.

[41] Le Roux A, Wahl Z. Namaqualand: South African wild flower guide. Cape Town: Botanical Society of South Africa; 2005.

[42] Henschel J, et al. !Nara: Fruit for development of the !Khuiseb Topnaar. Windhoek: John Meinert Printing; 2004.

[43] Mizuno K, Yamagata K. Vegetation succession and plant use in relation to environmental changes along the Kuiseb river in the Namib Desert. Afr Stud Monogr 2005; 30: 3-4.

[44] Fry C. Seeds: A natural history. Chicago: University of Chicago Press; 2016. https://doi.org/10.7208/chicago/9780226224497.001.0001

[45] Van Wyk B-E, Gericke N. People's plants. A guide to useful plants of southern Africa. Pretoria: Briza Publications; 2018.

[46] Nortje JM, Van Wyk B-E. Useful plants of Namaqualand, South Africa: A checklist and analysis. S Afr J Bot 2019; 122: 120-35. https://doi.org/10.1016/j.sajb.2019.03.039

[47] Sandelowsky BH. Acanthosicyos horridus, a multipurpose plant of the Namib Desert in south-western Africa. In Bates 
DM, Robinson RW, Jeffrey C (Eds.), Biology and utilization of the Cucurbitaceae. New York: Cornell University Press; 1990, pp. 349-55. https://doi.org/10.7591/9781501745447-030

[48] Dentlinger U. An ethnobotanical study of the !nara plant among the Topnaar hottentots of Namibia. Munger Afr Libr Notes 1977; 38: 1-39.

[49] Sandelowsky BH. Mirabib: An archaeological study in the Namib. Madoqua 1977; 10(4): 221-83.

[50] Schwartz HM, Burke RP. The chemistry of nara seed (Acanthosicyos horrida, Hook) III. The amino acid composition of the protein. J Sci Food Agr 1958; 9: 159-62. https://doi.org/10.1002/jsfa.2740090307

[51] Cunningham $A B$. The role of ethnobotany and indigenous knowledge in conservation of plant genetic resources. Dinteria 1992; 23: 119-31.

[52] Sarafis V. Cucurbit resources in Namibia. In Janick J (Ed.), Perspectives on new crops and new uses. Alexandria VA: ASHS Press, 1999, pp. 400-2.

[53] Bennett B. Linking natural product producer and processor organisations to natural product enterprises: A discussion of past, present and future models. Windhoek: Indigenous Plant Products in Namibia; 2014, pp. 134-41.

[54] Pfeifer EH. !Nara and Topnaar hottentots. S West Afr Annual 1979; 19: 158-9.

[55] Sherman C, et al. Abiotic and plant gender effects on the structure and function of soil microbial communities associated with Acanthosicyos horridus (Nara) in the Namibian sand-dune desert ecosystem. J Arid Environ 2019; 163: $50-8$.

https://doi.org/10.1016/j.jaridenv.2019.01.009

[56] Bates DM, Robinson RW, Jeffrey C. Biology and utilization of the Cucurbitaceae. New York: Cornell University Press; 1990. https://doi.org/10.7591/9781501745447

[57] Van Den Eynden V, Vernemmen P, Van Damme P. The ethnobotany of the Topnaar. Ghent: Ghent University; 1992.

[58] Berry C. Aspects of phenology and condition of inland and coastal !Nara plants in the Namib-Naukluft Park, Namibia. Dinteria 2003; 28: 1-18.

[59] Wickens GE, Goodin JR, Field DV. Plants for arid lands. Richmond: Royal Botanic Gardens, Kew; 1985. https://doi.org/10.1007/978-94-011-6830-4

[60] Van Damme P, Van Den Eynden V. Succulent and xerophytic plants used by the Topnaar of Namibia. Haseltonia 2000; 7: 53-62.

[61] Cock IE. Medicinal plant images. Pharmacogn Comm 2014; 4(3): 88-9.

[62] Quattrocchi U. CRC world dictionary of medicinal and poisonous plants: common names, scientific names, eponyms, synonyms, and etymology. London: CRC Press; 2012.

[63] Mulyangote LT. Ethnobotany and bioactivity of medicinal plants used to treat symptoms associated with gastrointestinal infections in Namibia. MSc Dissertation. Windhoek: University of Namibia; 2016.

[64] Joubert FJ, Cooper DC. Chemistry of naras seed (Acanthosicyos horridus Hook.). Part 1: A physico-chemical study of the protein from naras seed. J S Afr Chem Institute 1954; $7: 99$
[65] Tanaka J. The San, hunter-gatherers of the Kalahari: A study in ecological anthropology. New York: Columbia University Press; 1980.

[66] Wehmeyer AS. Edible wild plants of southern Africa: Data on the nutrient contents of over 300 species. Pretoria: CSIR; 1986.

[67] Eaton SB, Nelson DA. Calcium in evolutionary perspective. American J Clinical Nutr 1991; 54: 28I-7.

[68] Klopatek JM, Stock WD. Partitioning of nutrients in Acanthosicyos horridus, a keystone endemic species in the Namib desert. J Arid Environ 1994; 26: 233-40. https://doi.org/10.1006/jare.1994.1026

[69] Velempini K, Perkins JS. Integrating indigenous technica knowledge and modern scientific knowledge for biodiversity conservation and human livelihoods in the southern Kalahari, Botswana. Botswana Notes Rec 2008; 39: 75-88.

[70] Yang R-Y, Keding GB. Nutritional contributions of important african indigenous vegetables. In Shackleton CM, Pasquin MW, Drescher AW (Eds.), African indigenous vegetables in urban agriculture. London: Earthscan; 2009, pp. 103-43.

[71] Cheikhyoussef $\mathrm{N}$, et al. Characterization of Acanthosicyos horridus and Citrullus lanatus seed oils: Two melon seed oils from Namibia used in food and cosmetics applications. 3 Biotech 2017; 7: 297. https://doi.org/10.1007/s13205-017-0922-3

[72] Effiong GS, Ibia TO, Udofia US. Nutritive and energy values of some wild fruit spices in southeastern Nigeria. Electronic $\mathrm{J}$ Environ Agr Food Chem 2009; 8(10): 917-23.

[73] Ruiz-Rodríguez BM, et al. Valorization of wild strawberry-tree fruits (Arbutus unedo L.) through nutritional assessment and natural production data. Food Res Int 2011; 44(5): 1244-53. https://doi.org/10.1016/j.foodres.2010.11.015

[74] Liu Y, Heying E, Tanumihardjo S. History, global distribution, and nutritional importance of citrus fruits. Compreh Rev Food Sci Food Safety 2012; 11: 530-45.

\section{https://doi.org/10.1111/j.1541-4337.2012.00201.x}

[75] Rehm S, et al. Bitter principles of the Cucurbitaceae. VII. The distribution of bitter principles in this plant family. J Sci Food Agr 1957; 8: 679-86. https://doi.org/10.1002/jsfa.2740081203

[76] Hylands PJ, Magd MS. Cucurbitacins from Acanthosicyos horridus. Phytochem 1986; 25(7): 1681-4. https://doi.org/10.1016/S0031-9422(00)81235-2

[77] Miró M. Cucurbitacins and their pharmacological effects Phytoth Res 1995; 9: 159-68. https://doi.org/10.1002/ptr.2650090302

[78] Polya G. Biochemical targets of plant bioactive compounds: A pharmacological reference guide to sites of action and biological effects. London: CRS Press, 2003. https://doi.org/10.1201/9780203013717

[79] Hebeler F. Structural and ecophysiological shoot features of the leafless cucurbit Acanthosicyos horridus, a keystone endemic of the Namib desert. MSc Dissertation. Giessen: University of Giessen; 2000.

[80] Van Wyk B-E, Wink M. Phytomedicines: Herbal drugs and plant poisons. Pretoria: Briza Publications; 2014. https://doi.org/10.7208/chicago/9780226205076.001.0001

[81] Schmidt BM, Cheng DMK. Ethnobotany: A phytochemical perspective. London: Wiley Blackwell; 2017. https://doi.org/10.1002/9781118961933

\section{DOI: https://doi.org/10.29169/1927-5951.2020.10.05.13}

(C) 2020 Alfred Maroyi; Licensee SET Publisher.

This is an open access article licensed under the terms of the Creative Commons Attribution Non-Commercial License (http://creativecommons.org/licenses/by-nc/3.0/) which permits unrestricted, non-commercial use, distribution and reproduction in any medium, provided the work is properly cited. 